\title{
Myxobacteria in Soils and Composts; their Distribution, Number and Lytic Action on Bacteria
}

\author{
By B. N. SINGH \\ Department of Soil Microbiology, Rothamsted Experimental Station, Harpenden, Herts
}

SUMMARY: Myxococcus virescens, $M$. fulvus, Chondrococcus exiguus and Archangium sp. are widely distributed in the soils of Great Britain including some treated only with artificial fertilizers. Myxococcus virescens and Chondrococcus exiguus appear to be the dominant species. The numbers of myxobacteria ranged from 2000 to $76,400 / \mathrm{g}$. of soil. In an actively decomposing compost of sludge and straw the number of Myxococcus fulvus was found to be over 500,000/g.; M. virescens and Chondrococcus exiguus were also present, but less abundantly.

Variation of $\mathrm{pH}$ between 4.0 and 8.8 does not affect the growth of Myxococcus fulvus, $M$. virescens and Chondrococcus exiguus, and normal fruiting bodies were produced in the presence of suitable bacteria. Myxococcus fulvus and M. virescens do not attack filter paper.

Both Gram-positive and Gram-negative bacteria growing on solid media may be lysed by extracellular secretions of $M$. virescens, $M$. fulvus and Chondrococcus exiguus. Of forty-seven Gram-positive and forty-seven Gram-negative strains of bacteria tested with three species of myxobacteria, a higher percentage of Gramnegative than of Gram-positive strains was attacked. Pigmented strains of bacteria are more resistant to the lytic action of myxobacteria than the non-pigmented strains. Different species of myxobacteria and different strains of the same species differ in their lytic action on a number of species of bacteria.

The extracellular lytic substance produced by Myxococcus virescens passes through a cellophan membrane. A method of growing $M$. fulvus and $M$. virescens in mass cultures in liquid media to produce extracellular lytic secretions is described.

Myxobacteria were recognized as an independent group. by Thaxter (1892). Although over fifty species have been described we know very little indeed about these interesting organisms apart from their morphology, and some are known only by the description of their fruiting bodies. The favourable influence of bacteria and fungi on the growth of myxobacteria was stressed by earlier workers. Pinoy (1921) was the first to observe the lysis of an unspecified Micrococcus by Chondromyces crocatus on a nutrient agar and recently Solntzeva (1939) has studied the lytic effect of Chondromyces aurantica, Milittangium boletus, Myxococcus rubescens, $\boldsymbol{M}$. virescens and $\boldsymbol{M}$. filiformis on five species of plant pathogenic bacteria. She grew the plant pathogens for 2 days on peptone + starch agar and then introduced myxobacteria into the culture. Some lysis of a few species of bacteria could be seen. When dilute suspensions of microcysts from fruiting bodies grown on rabbit-dung pellets were plated on manure extract + proteose peptone + glucose agar, Snieszko, McAllister \& Hitchner (1943) observed the occasional lysis of the portions of the surface colonies of associated Gram-negative bacteria by $M$. virescens. They also showed the lysis of dead bacteria by $M$. virescens and $M$. fulvus. Beebe (1941b) has shown that a few species of dead bacteria are lysed by Polyangium fuscum, Podangium erectum, Chondrococcus blasticus, Myxococcus fulvus and $\boldsymbol{M}$. virescens. 
Although no conclusive evidence has been produced of the lysis of living bacteria by myxobacteria, it is suggested by the work of Pinoy (1921) and Solntzeva (1939). All the known higher myxobacteria so far investigated fall into two main groups: (i) those capable of effecting either partial or complete decomposition of cellulose (Krzemieniewski, 1937b; Imsenecki \& Solntzeva, 1937; Mishustin, 1938); (ii) those capable of attacking living or dead cells of true bacteria, and possibly of other micro-organisms, and developing normally when these cells are the only food. For the first group the term 'cellulolytic' and for the second 'bacteriolytic' may be used.

Myxobacteria were considered by earlier workers to be dung organisms because they were first isolated from dung of various animals that had lain on the ground for some time. The Krzemieniewski (1926, 1937 a) claim to have isolated a large number of species from various Polish soils by putting sterilized rabbit dung on 100-150 g. of soil in large Petri dishes. By the same method Beebe (1941 $a$ ) isolated from American soils species belonging to Myxococcaceae and Polyangiaceae. The most common species belong to the genus Myxococcus. Apart from isolating myxobacteria from large quantities of soil, no effort has been made to find out how commonly they are present, as a preliminary to assessing their economic importance in soil or other substrates.

The present study of the myxobacteria followed the development of a method of counting holozoic soil Protozoa based on their differential feeding on different bacteria (Singh, 1942, 1945, 1946a, $b$ ). By this method soil and compost heaps proved to contain significant numbers of certain species of myxobacteria, lysing both Gram-positive and Gram-negative bacteria. The study of differential feeding of Protozoa on bacteria has also led to methods of isolating and purifying lytic species of myxobacteria from soils and other substrates and of counting them.

\section{Methods of isolation and culture}

The method of isolation is similar to that used for Acrasieae (Singh, 1946c). It consists in spreading over the surface of non-nutrient agar $(1.5 \%$ washed agar, $0 \cdot 5 \% \mathrm{NaCl}$ ) of $\mathrm{pH} 6 \cdot 6-7 \cdot 2$, or silica jelly (for method of preparation see Singh, 1946b), a few loopfuls of a suitable bacterium in the form of disks or 'bacterial circles' about 1 in. in diameter. Aerobacter, strain 1912 (Singh, 1941), was used throughout the work described below.

The bacteria used are taken from 2-4-day cultures on nutrient agar. Several such 'bacterial circles' are made in a Petri dish. These circles are inoculated at the centre either with very small crumbs of soil or with a very small portion of a substrate such as decomposing compost, or with suspensions of soil or other substrates. The plates are incubated at $25^{\circ}$ for 1-3 weeks and examined at intervals under a low power of a microscope. In these crude cultures large numbers of fruiting bodies of myxobacteria are usually found.

The crude cultures contain large numbers of amoeba cysts if a suitable bacterium for the development of amoebae is used. In order to discourage the development of amoebae, strains of bacteria are selected that are not suitable for the growth of amoebae, but are readily attacked by lytic myxobacteria. 
It is best to use a suitable strain of Gram-negative organism, because it does not encourage the growth of the lytic actinomycetes which are abundantly present in arable soils.

The myxobacteria are purified as follows: bacterial streaks generally $\mathbf{1}$ in. long and $0 \cdot 3-0.4$ in. broad are made on non-nutrient agar or silica jelly and fruiting bodies are placed in contact with the bacteria at one end of the streaks. These bacterial streaks are cleared by the contaminating amoebae and by the myxobacteria within a week; some of the fruiting bodies or a portion of a swarm of myxobacteria which are formed away from the amoebae are transferred to fresh streaks. This process is repeated once or twice till a mixed culture of myxobacteria and bacteria only is obtained. The fruiting bodies formed outside the zone of bacterial streaks are now transferred to the centre of a 'bacterial circle' made with a thick suspension of a young culture in $0.9 \% \mathrm{NaCl}$ autoclaved at $15 \mathrm{lb}$./sq.in. for 5-10 min. The myxobacteria clear the dead 'bacterial circle' in a few days and form a large number of fruiting bodies. Some of these bodies from the edge of the circle are suspended in $0.9 \% \mathrm{NaCl}$ and plated in the usual way on non-nutrient agar containing a thick suspension of autoclaved bacteria, and incubated at $25^{\circ}$.

After a few days myxobacterial colonies develop and lyse the dead bacteria (Pl. 1, figs. 3, 4). The colonies look like those of true bacteria, smooth, flat and with entire edge; no swarming of the myxobacterial rods can be seen at the edge. The colonies are at first white, but gradually become coloured as the fruiting bodies are formed. The fruiting bodies appear in large numbers in 7-15 days, sometimes at the circumference of the colony and sometimes at the centre; finally the whole of the colony is converted into fruiting bodies.

Sub-cultures from the fruiting bodies are made on dead bacterial agar every 1-2 months, and their purity tested on nutrient agar, on which myxobacteria generally grow well but do not produce fruiting bodies. Cultures maintained on nutrient agar have to be sub-cultured every 7-10 days, as myxobacteria autolyse within 10-15 days (Snieszko et al. 1943). Pure cultures of species of Myxococcus have been maintained both on nutrient agar and on dead bacterial agar for more than 2 years. Whenever myxobacteria growing on nutrient agar are transferred to suitable strains of either dead or living bacteria on nonnutrient agar, they readily lyse the bacteria and large numbers of fruiting bodies are formed.

In addition to the media described above, sterilized fresh rabbit dung was also used to isolate myxobacteria from soils and composts but with disappointing results. The rabbit dung used was from tame rabbits and it is possible that fresh dung from wild rabbits would give better results.

\section{Distribution and number of myxobacteria in soil and compost}

Beebe (1941 $a$ ) isolated only a few species of myxobacteria, mostly members of the Myxococcaceae, from American soils and this has also been the experience of the author with the soils of Great Britain. It is quite possible that as in the method used such a small sample of soil ( $0.5 \mathrm{~g}$. or less) is examined only species present in large numbers have been found. Moreover, the use of 
bacterial strains may have completely prevented the isolation of those species which do not attack bacteria.

Sixty-nine soil samples from Hertfordshire, Berkshire, Bedfordshire, Wiltshire, Kent, Cornwall, Glamorganshire, Breconshire and Aberdeen were examined together with soils of all the classical plots of Barnfield and Broadbalk and a number of other fields at Rothamsted. The samples were taken from the top few inches of the soil. Myxobacteria were present in all the arable soils and in twenty-one of the thirty-one grassland soils. The occurrence of myxobacteria in large numbers in the classical plots of Barnfield, Broadbalk and other fields at Rothamsted, where no farmyard manure has been added, in some cases for 100 years or more, disproves the earlier belief that myxobacteria are dung organisms. Their common occurrence in dung of various animals that has been lying on the ground for several days suggests that they find suitable nutritive material in those substrates.

No correlation between the $\mathrm{pH}$ of the soils and the distribution of species could be found in soils ranging from $\mathrm{pH} 4 \cdot 0-8 \cdot 0$, although a correlation with soil $\mathrm{pH}$ was claimed by the Krzemieniewski (1926).

On several occasions a few species belonging to groups other than the Myxococcaceae were present both in bacterial and in rabbit-dung cultures used to isolate species of myxobacteria. They did not grow in culture; and, until this is done, it does not appear justifiable to name them from the fruiting bodies.

Myxococcus virescens, $M$. fulvus, Chondrococcus exiguus and Archangium sp. are the species which have so far been isolated and cultured from soils very widely scattered in Great Britain (Pls. 1 and 2, figs. 1-8). Myxococcus virescens, Chondrococcus exiguus and Archangium sp. were very commonly found in soil, but in the few samples of decomposing compost of sludge and straw examined Myxococcus fulvus occurred in much larger numbers than the other three species.

When nineteen strains of bacteria consisting of both Gram-positive and Gram-negative were selected at random, and used to isolate species of myxobacteria from the farmyard manured soils of Barnfield and Broadbalk plots at Rothamsted only the four species mentioned above could be isolated.

A few counts have been made by the dilution method of Singh $(1946 a, b)$ on Barnfield farmyard manured soil and on a decomposing compost heap of sludge and straw set up at Rothamsted farm. The identification of myxobacteria at various dilutions was by the fruiting bodies. Table 1 shows three counts made on different dates from Barnfield farmyard manured soil, using Aerobacter on non-nutrient agar substrate. In every case Myxococcus virescens was dominant.

Two counts were made from an actively decomposing compost of sludge and straw in March 1945, from samples taken at 3 and 6 in. depth, on Aerobacter in silica jelly. The numbers of myxobacteria were found to be over $500,000 / \mathrm{g}$. of compost from the sample taken at $3 \mathrm{in}$. depth and not more than 1000 at $6 \mathrm{in}$. depth, where the temperatures were respectively $30^{\circ}$ and $36^{\circ}$. It is possible that anaerobic conditions or the increase in temperature, or both, may account for this big difference in numbers at different depths. 
Myxococcus fulvus, $M$. virescens and Chondrococcus exiguus were isolated and purified from these crude cultures. Myxococcus fulvus alone was present in the very high dilutions. The result of this count in compost suggests that a detailed study of this group of organisms in various types of composts (hot and cold) might be interesting, especially as nothing is known about the role of myxobacteria in soil or in decomposing compost heaps.

Table 1. Counts of lytic myxobacteria in an arable soil

$\begin{array}{cc}\text { Barnfield } & \text { Number of myxobacteria } \\ \text { farmyard manured soil } & \text { per g. } \\ \text { First count } & \mathbf{7 6 , 3 9 9} \\ \text { Second count } & \mathbf{6 , 0 0 0} \\ \text { Third count } & \mathbf{2 , 0 0 0}\end{array}$

\section{Effect of $\mathrm{pH}$ on the growth of myxobacteria}

The effect of $\mathrm{pH}$ on the growth of $M$. virescens, $M$. fulvus and Chondrococcus exiguus was tested as follows. Non-nutrient agar was adjusted to $\mathrm{pH} 4 \cdot \mathbf{0}, \mathbf{4} \cdot \mathbf{6}$, $5 \cdot 0,5 \cdot 5,6 \cdot 0,6 \cdot 6,7 \cdot 0,7 \cdot 5,8 \cdot 1$ and $8 \cdot 8$. The agar was poured into Petri dishes, streaked with Aerobacter sp., and inoculated with fruiting bodies of myxobacteria. All species grew well and produced normal fruiting bodies at all the $\mathrm{pH}$ values.

\section{Growth of Myxococcus virescens and M. fulvus on filter paper in the presence and absence of bacterial suspensions}

When fruiting bodies from pure cultures of $\boldsymbol{M}$. virescens and $\boldsymbol{M}$. fulvus were transferred to strips of filter paper dipped in mineral salt solution (0.1\% $\mathrm{K}_{2} \mathrm{HPO}_{4}, 0.05 \% \mathrm{KCl}, 0.05 \% \mathrm{MgSO}_{4}, 0.1 \% \mathrm{NaNO}_{3}$, trace of $\mathrm{FeSO}_{4}$ ) in testtubes and incubated at $25^{\circ}$, no apparent growth or decomposition of the filter paper took place up to 2 months. When a suspension of dead bacteria was added to the solution both the $M$. virescens and $M$. fulvus grew well and produced large numbers of fruiting bodies. The fruiting bodies were mostly formed on the glass, and some on the filter paper above the surface of the liquid. Thick bacterial suspensions were usually cleared within 2 weeks. Cultures maintained for more than 2 months on strips of filter paper in suspensions of dead bacteria did not show any sign of decomposing the filter paper.

Some workers have used a dilution method of counting Sporocytophaga myxococcoides (Spirocheta cytophaga; see Stanier, 1942a), noting the yellow colour developing on filter paper, which is decomposed. When Myxococcus virescens is put on filter paper in the presence of a bacterial suspension it produces a colour like that of Sporocytophaga myxococcoides but does not decompose the paper. The method of counting $S$. myxococcoides is very unsatisfactory since there is no guarantee that both the yellow colour and the decomposition of filter paper is caused by $S$. myxococcoides. It is possible that the yellow colour is due to Myxococcus virescens and the decomposition of the filter paper is due to cellulose-decomposing organisms other than Sporocytophaga myxococcoides. It is difficult to be certain of the presence of $S$. myxococcoides by microscopic examination since the vegetative cells both of it and 
of Myxococcus virescens are alike. The only way to make sure of the presence of Sporocytophaga myxococcoides is to isolate this organism from every dilution or at least from a few higher dilutions where the yellow colour is associated with the decomposition of filter paper.

\section{Lysis of living bacterial strains by species of Myxococcaceae on solid media}

Myxococcus virescens, M. fulvus and Chondrococcus exiguus isolated from a decomposing compost heap, and a strain of Myxococcus virescens isolated from a Rothamsted soil, were tested for bacteriolytic activity as follows. Three widely separated streaks of a 2-4-day culture of a bacterium on nutrient agar

Table 2. The lysis of bacterial strains by myxobacteria $\mathrm{CL}=$ Completely lysed either readily or slowly; $\mathrm{PL}=$ very slight partial lysis;

$$
\mathrm{NL}=\text { not lysed. }
$$

\begin{tabular}{|c|c|c|c|c|c|c|c|c|c|c|}
\hline & \multicolumn{3}{|c|}{ M. virescens } & \multicolumn{3}{|c|}{ M. fulvus } & \multicolumn{3}{|c|}{ C. exiguus } & \multirow{2}{*}{$\begin{array}{c}\text { Total } \\
\text { strains } \\
\text { tested }\end{array}$} \\
\hline & CL & PL & NL & CL & PL & NL & CL & PL & NL & \\
\hline $\begin{array}{l}\text { Common soil } \\
\text { bacteria }\end{array}$ & 9 & $\mathbf{I}$ & 1 & 10 & 一 & 1 & 8 & 3 & - & 11 \\
\hline Rare soil bacteria & 16 & 10 & $\mathbf{3}$ & 8 & 12 & 9 & $\mathbf{5}$ & 10 & 14 & 29 \\
\hline Plant pathogens* & $\mathbf{9}$ & - & 1 & 9 & - & 1 & $\mathbf{9}$ & - & 1 & 10 \\
\hline Strains & $\mathbf{3}$ & 6 & $\mathbf{3}$ & 4 & 4 & 4 & 3 & 6 & 3 & 12 \\
\hline
\end{tabular}

* The strains $(4752,5945,1989,5944,5942,385,5943,387,5241$ and 1997) of plant pathogens were obtained from the National Collection of Type Cultures, Lister Institute. See Singh (1942) for the names of the plant pathogens used.

were made on non-nutrient agar. Two streaks were inoculated at one end with fruiting bodies of one of the myxobacteria growing with living Aerobacter sp. and the third was left as control. The cultures were incubated at $25^{\circ}$ and examined at 5 and 10 days. Of the bacteria tested by this method some were readily or slowly but completely lysed, others showed very slight partial lysis and the rest were not lysed within a period of 10-12 days. Table 2 shows the lytic action of the three species of Myxococcaceae on sixty-two strains of various bacteria. The three species differ in their reactions towards the same strain of bacteria in a number of cases. Against Rhizobium and plant pathogens they behave, on the whole, in a similar manner, nearly all the plant pathogens being readily attacked whereas the strains of Rhizobium seem to be resistant. Two strains of Myxococcus virescens, one isolated from a compost heap and the other from a soil, differed in their lytic action towards eight of the fifty-six strains of bacteria. Some strains of bacteria, not lysed by the soil strain of $M$. virescens, were lysed by the strain isolated from compost and vice versa. Pigmented strains seem to be more resistant than the non-pigmented (see Table 3). In Table 4 the lytic action towards Gram-positive and Gramnegative organisms is shown. Though both Gram-positive and Gram-negative bacteria are attacked, more Gram-negative than Gram-positive strains are attacked except by $M$. virescens.

Nineteen strains of soil bacteria were tested to see whether the Myxococcaceae actually attack living bacteria on solid media or only lyse cells that 
are dead. After 10 days' incubation, slopes of nutrient agar were streaked with samples from the control cultures, and material from the lysed areas on the plates supplied with myxobacteria was similarly subcultured. Growth of the samples from the control streaks was profuse in $24 \mathrm{hr}$. at $25^{\circ}$ while those from areas lysed by $\boldsymbol{M}$. fulvus in every case grew only slightly within 2-4 days. Subcultures from the lysed areas produced by $\boldsymbol{M}$. virescens on sixteen strains of bacteria failed to grow in seven cases, even after 10 days' incubation, whereas nine gave positive results within 2-5 days. Cultures from areas lysed by Chondrococcus exiguus were positive with nine strains of bacteria tested and negative with two.

Table 3. The lysis of pigmented and non-pigmented strains of bacteria by myxobacteria. (Strains of Rhizobium have been excluded) $\mathrm{CL}=$ Completely lysed either readily or slowly; $\mathrm{PL}=$ very slight partial lysis; NL $=$ not lysed.

\begin{tabular}{|c|c|c|c|c|c|c|c|c|c|c|}
\hline \multirow[b]{3}{*}{$\begin{array}{c}\text { Pigmented } \\
\text { bacteria }\end{array}$} & \multirow{2}{*}{$\begin{array}{l}\text { No. of } \\
\text { strains } \\
\text { tested }\end{array}$} & \multicolumn{3}{|c|}{ M. virescens } & \multicolumn{3}{|c|}{ M. fulvus } & \multicolumn{3}{|c|}{ C. exiguus } \\
\hline & & $\%$ CL & $\%$ PL & $\stackrel{\% \mathrm{NL}}{\mathrm{N}}$ & $\% \mathrm{CL}$ & $\%$ PL & $\widehat{\% \mathrm{NL}}$ & $\% \mathrm{CL}$ & $\% \mathbf{P L}$ & $\% \mathrm{NL}$ \\
\hline & 41 & $63 \cdot 4$ & $19 \cdot 5$ & 17 & $41 \cdot 4$ & $\mathbf{3 4 \cdot 2}$ & $24 \cdot 4$ & $36 \cdot 5$ & $24 \cdot 4$ & $39 \cdot 1$ \\
\hline $\begin{array}{l}\text { Non-pigmented } \\
\text { bacteria }\end{array}$ & 52 & 75 & $17 \cdot 3$ & $7 \cdot 6$ & $67 \cdot 3$ & $19 \cdot 2$ & $13 \cdot 4$ & $59 \cdot 5$ & 25 & $15 \cdot 5$ \\
\hline
\end{tabular}

Table 4. The lysis of Gram-positive and Gram-negative bacteria by myxobacteria. (Strains of Rhizobium have been excluded)

$\mathrm{CL}=$ Completely lysed either readily or slowly; $\mathrm{PL}=$ very slight partial lysis; $\mathrm{NL}=$ not lysed.

\begin{tabular}{|c|c|c|c|c|c|c|c|c|c|c|}
\hline & \multirow{2}{*}{$\begin{array}{l}\text { No. of } \\
\text { strains } \\
\text { tested }\end{array}$} & \multicolumn{3}{|c|}{ M. virescens } & \multicolumn{3}{|c|}{ M. fulvus } & \multicolumn{3}{|c|}{ C. exiguus } \\
\hline & & $\% \mathbf{C L}$ & $\% \mathbf{P L}$ & $\%$ NL & CL & $\% \mathbf{P L}$ & $\% \mathrm{NL}$ & $\% \mathrm{CL}$ & $\% \mathrm{PL}$ & NL \\
\hline & 47 & 68 & 21 & & & 34 & & 31.9 & $38 \cdot 3$ & 8 \\
\hline & 47 & $74 \cdot 4$ & 14.9 & $10 \cdot 6$ & $\mathbf{7 4 \cdot 4}$ & 17 & 8.5 & 68 & $10 \cdot 7$ & $21 \cdot 2$ \\
\hline
\end{tabular}

In a second experiment, asparagine agar (Thornton, 1922) was selected as a substrate allowing slow bacterial growth. A loopful of Aerobacter sp. from a 36-hr. culture was streaked on asparagine agar in a Petri dish and inoculated with fruiting bodies of Myxococcus virescens. Roughly the same amount of bacteria was streaked as a control. Pl. 2, figs. 9 and 10, show the results obtained. It is clear that in 4 days $M$. virescens had completely lysed the growing cells of the bacteria and large numbers of fruiting bodies were produced. When a pure culture of the fruiting bodies of $\boldsymbol{M}$. virescens is inoculated on asparagine agar, it grows slowly but does not produce fruiting bodies. The lysis of living cells of Aerobacter sp. on asparagine agar by $\boldsymbol{M}$. fulvus and Chondrococcus exiguus is not so spectacular as that by Myxococcus virescens; it is not complete until after 5-7 days. $M$. fulvus and Chondrococcus exiguus grow well on this medium but they too do not produce fruiting bodies in the absence of suitable bacteria.

The numbers of bacteria viable in the control and the lysed area were determined as follows. A loopful of bacteria from the edge and from the centre of the control streak on the 4th day (see Pl. 2, figs. 9, 10) were each 
suspended in $10 \mathrm{ml}$. of $0.9 \% \mathrm{NaCl}$ solution and a total count made in a haemocytometer. The number of viable bacteria was determined by plating dilutions of the suspensions. Similarly, one loopful of myxobacterial growth from the lysed area was suspended in $10 \mathrm{ml}$. of $\mathrm{NaCl}$ solution; the suspension was diluted one-hundred-fold and plated for counting. The control bacterial growth contained 74-85\% viable cells. In areas lysed by Myxococcus fulvus very few living cells of Aerobacter sp. were found and none in areas lysed by Myxococcus virescens or Chondrococcus exiguus. These data show that the myxobacteria kill the living bacteria and do not merely lyse dead bacterial cells.

It has been repeatedly found that the pigmentation of both Myxococcus virescens and $M$. fulvus is influenced by the bacterial strain supplied as food. The fruiting bodies of $M$. virescens were found to be brown, brick red, whitish, yellowish red, etc., according to the strain of bacterium used; the pigmentation of $M$. fulvus varied in the same way but less markedly. Similar variations in pigmentation were noticed by Snieszko et al. (1943). The size of the fruiting bodies is also influenced by the type of bacteria used. Different shapes of fruiting bodies are produced even in the same culture (see Stanier, 1942 $b$, for the explanation of this phenomenon). In the past, species have been based on the size, shape and pigmentation of fruiting bodies. In the light of the above results, it must be emphasized that the characters can only be used for diagnostic purposes when the organisms have been grown under strictly controlled conditions.

\section{Passage of the lytic substance of $\mathrm{M}$. virescens through cellophan}

The experiment was arranged as follows. In the centre of non-nutrient agar plates a few loopfuls of Aerobacter sp. from a 2-day culture on nutrient agar was spread out as a thin layer; a sterilized cellophan membrane was laid over this and on the upper surface microcysts from a pure culture of Myxococcus virescens were streaked in the centre of the plate. Within 2 weeks it could be seen that a very large proportion of the bacteria beneath the cellophan had been lysed, and large numbers of fruiting bodies were formed on the top of the membrane. No decomposition of cellophan occurred within a month. From this experiment it is clear that the bacteriolytic substance produced by $M$. virescens passes through cellophan, and the products of lysis diffuse through cellophan and supply nutrient material for the myxobacteria.

\section{Method of growing M. virescens and M. fulvus in mass liquid culture to produce the lytic substance}

Since it was observed that both $\boldsymbol{M}$. virescens and $\boldsymbol{M}$. fulvus produced fruiting bodies only above the surface of liquid media and that in a decomposing compost heap at a depth of 6 in. myxobacteria were present only in very small numbers, it was thought that they needed air for luxuriant growth. The organisms were grown in liquid media as follows : 5-7 days' growth of Aerobacter sp. from nutrient agar slope was gently scraped off in $0.9 \% \mathrm{NaCl}$ solution and collected in a flask. $750 \mathrm{ml}$. flasks containing $75 \mathrm{ml}$. of $0.9 \% \mathrm{NaCl}$ solution and $25 \mathrm{ml}$. of the thick suspension of bacteria were autoclaved at $15 \mathrm{lb}$. $/ \mathrm{sq}$.in. 
for $10 \mathrm{~min}$. Myxobacteria growing in pure culture, either on nutrient agar or on dead bacterial suspension agar, were inoculated into these flasks and incubated at $25^{\circ}$.

Within 2 weeks the bacterial suspensions were completely cleared, and good growth of the myxobacterial colonies on the glass below the shallow layer of liquid could be seen within a week. These colonies were sometimes very large and gelatinous; they were white at first and later coloured as the fruiting bodies formed. Within 2-3 weeks very large numbers of fruiting bodies were formed both on the bottom of the flask below the liquid and on the glass above the liquid surface. An improved development of fruiting bodies by Myxococcus virescens and $M$. fulvus on the bottom could be induced by covering the bottom of the flask with a layer of plain agar.

When suspensions of living Aerobacter sp. were used in flasks to grow myxobacteria, there was very little lysis of the bacteria up to a period of 2 weeks, and little growth of myxobacteria.

\section{DISCUSSION}

Although great attention has been paid in recent years to isolating antibiotics from various groups of micro-organisms, myxobacteria have so far received none. As some species of the Myxococcaceae lyse living bacteria, at least on solid media, a detailed study of the organisms belonging to the myxobacteria may be profitable in discovering new antibiotics active especially against Gram-negative organisms. The property of lysing Gram-negative organisms such as Pseudomonas fluorescens and Bacterium coli, by extracellular secretions, has rarely been found in other groups of micro-organisms. Moreover the fact that amoebae grow luxuriantly and produce cysts in crude cultures that also contain actively growing myxococci, suggests that the extracellular secretions of the myxococci do not affect amoebae, and hence may be non-toxic to animal tissues.

This work was made possible by a grant from the Agricultural Research Council, to whom the author's thanks are due.

It is a great pleasure to express my sincere thanks to Dr H. G. Thornton, F.R.S., and Miss L. M. Crump for their never failing interest in this work, and to Mr Victor Stansfield for his help in taking the photographs.

\section{REFERENCES}

BeEbe, J. M. (1941 $a$ ). Studies on the Myxobacteria. 1. Distribution in Central Iowa with description of a new species. Iorwa St. Coll. J. Sci. 15, 307.

Beebe, J. M. (1941 $b$ ). Studies on the Myxobacteria. 2. The role of Myxobacteria as bacterial parasites. Iowa St. Coll. J. Sci. 15, 319.

ImSenecki, A. \& Sonntzeva, L. (1937). On cellulose-decomposing Myxobacteria. Mikrobiologica, Moscow, 6, 3.

Krzemieniewsiki, Helena \& Siveryn (1926). Miksobakterje Polski. Acta Soc. Bot. Polon. 4, 1.

Krzemieniewski, Helena \& Siveryn (1937a). Die Zellulosezersetzenden Myxobakterien. Bull. int. Acad. Cracovie, B, Sci. Nat. 1, 11.

Krzemieniewsin, Helena \& Siveryn (1937b). Über die Zersetzung der Zellulose durch Myxobakterien. Bull. int. Acad. Cracovie, B, Sci. Nat. 1, 33.

Mishustin, E. N. (1938). Cellulose decomposing Myxobacteria. Microbiologica, Moscow, 7, 427. 
Pinoy, P. E. (1921). Sur les Myxobactéries. Ann. Inst. Pasteur, 35, 487.

SiNGH, B. N. (1941). Selectivity in bacterial food by soil amoebae in pure mixed culture and in sterilized soil. Ann. appl. Biol. 28, 52.

Singh, B. N. (1942). Selectivity of bacterial food by soil flagellates and amoebae. Ann. appl. Biol. 29, 18-22.

Singh, B. N. (1945). The selection of bacterial food by soil amoebae, and the toxic effects of bacterial pigments and other products on soil protozoa. Brit. J. exp. Path. 26, 316.

Singr, B. N. $(1946 a)$. A method of estimating the numbers of soil Protozoa, especially amoebae, based on differential feeding on bacteria by Protozoa. Ann. appl. Biol. 33, 112.

Singh, B. N. (1946b). Silica jelly as a substrate for counting holozoic Protozoa. Nature, Lond., 157, 302.

SiNGH, B. N. (1946c). Soil Acrasieae and their bacterial food supply. Nature, Lond., $157,133$.

Snieszko, S. F., McAllister, J. \& Hitchner, E. R. (1943). On the biology of certain Myxobacteria. Quart. Bull. Polish Inst. Arts Sci. Amer. 1, 651.

Solntzeva, L. I. (1939). On the lysis of phytopathogenic bacteria caused by Myxobacteriales. Mikrobiologica, Moscoze, 8, 700.

Stanier, R. Y. (1942 $a)$. The Cytophaga group: a contribution to the biology of Myxobacteria. Bact. Rev. 6, 143.

Stanier, R. Y. (1942b). A note on elasticotaxis in Myxobacteria. J. Bact. 44, 405.

Thaxter, R. (1892). On the Myxobacteriaceae, a new order of Schizomycetes. Bot. Gaz. 17, 389.

Thonnton, H. G. (1922). On the development of a standardized agar medium for counting soil bacteria with special regard to the repression of spreading colonies. Ann. appl. Biol. 9, 241.

\section{EXPLANATION OF PLATES}

Plate 1

Fig. 1. Vegetative cells of Myxococcus virescens fixed by Carnoy and stained by iron alum haematoxylin. $\times 1000$.

Fig. 2. Microcysts of M. virescens fixed by Carnoy and stained by iron alum haematoxylin. They are spherical or oval and never cup-shaped. $\times 1000$.

Fig. 3. Colonies of Chondrococcus exiguus developing on a suspension of dead Aerobacter sp. in agar. Five-days-old culture. Clearing of the bacterial cells round the colonies can be seen. $\times 4$.

Fig. 4. Colonies of $C$. exiguus similarly produced. Some colonies show the beginning of fruiting bodies formation as granular patches in the centre. $\times 4$.

Fig. 5. Fruiting bodies of Myxococcus virescens formed on sterilized rabbit dung. $\times 42$.

Fig. 6. Fruiting bodies of $M$. fulvus produced on non-nutrient agar with Aerobacter sp. as food supply. $\times 42$.

- Plate 2

Fig. 7. Fruiting bodies of Chondrococcus exiguus produced on non-nutrient agar with Aerobacter sp. as food supply. Photographed by reflected light. $\times 60$.

Fig. 8. The same as Fig. 7. Photographed by transmitted light.

Fig. 9. Growth of Aerobacter sp. on asparagine agar. Four-days-old culture (control). $\times 6$.

Fig. 10. Culture of the same age as in Fig. 9 inoculated with Myxococcus virescens showing large numbers of fruiting bodies and the complete lysis of Aerobacter sp. $\times 6$.

(Received 26 March 1946) 
Journal of General Microbiology, Vol. 1, No. 1

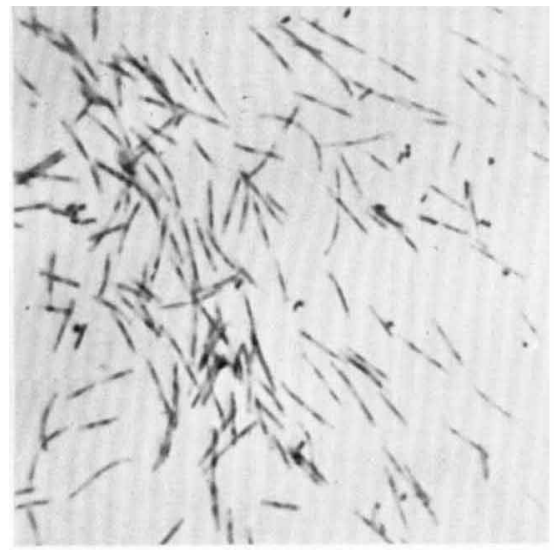

Fig. 1

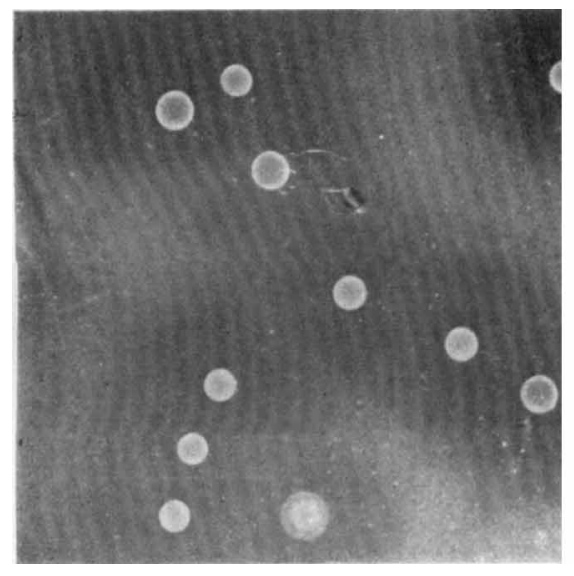

Fig. :3

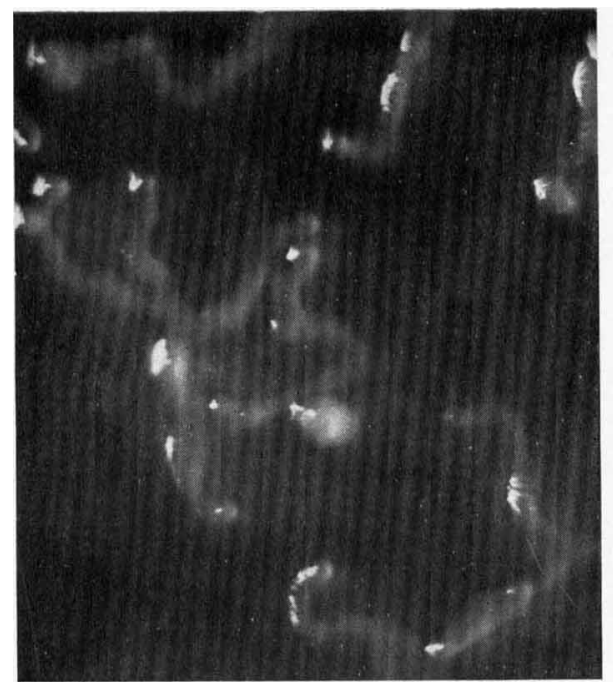

Fig. 5

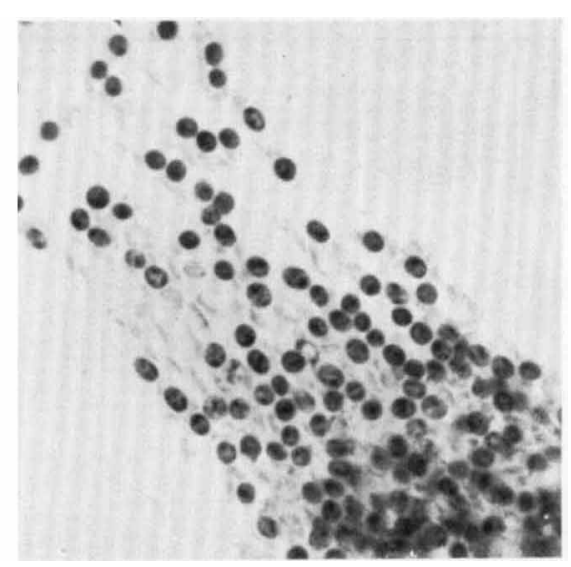

Fig. 2

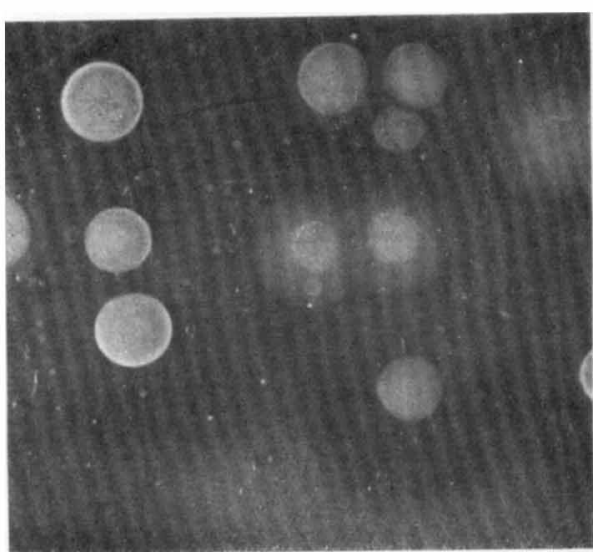

I'ig. 4

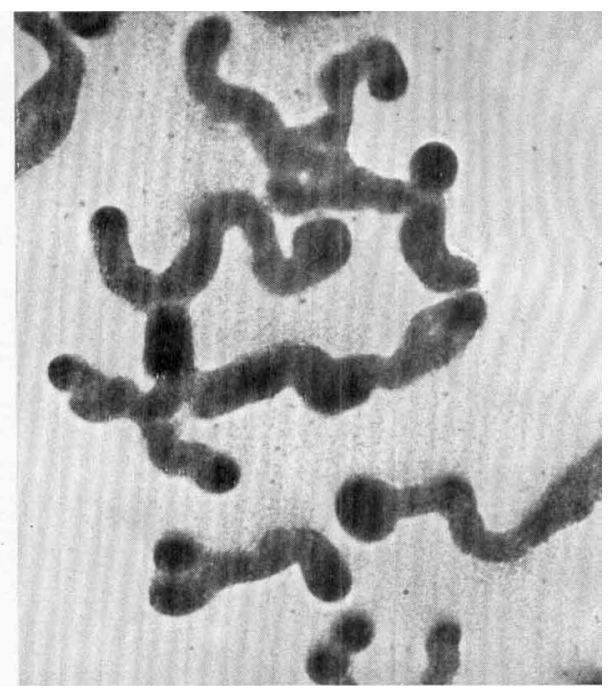

Fig. 6

13. N. Singi-Myxomactinia in soms. Prate 1 
Journal of General Microbiology, Vol. 1, No. 1

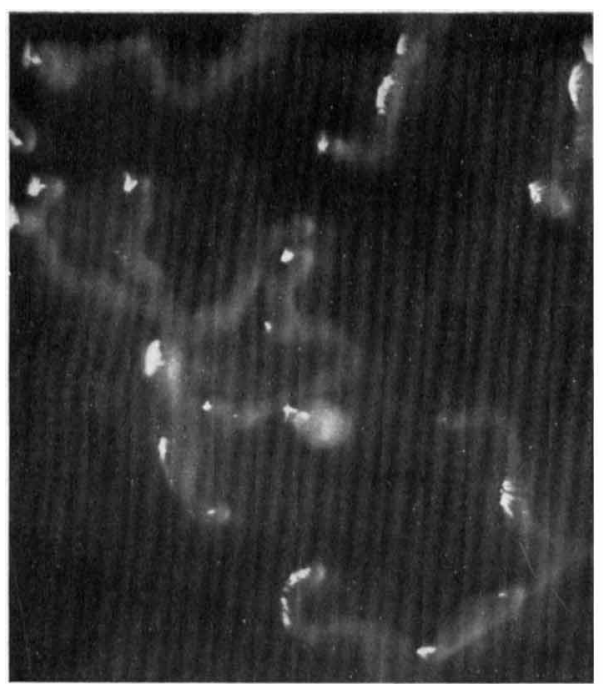

lig. 7

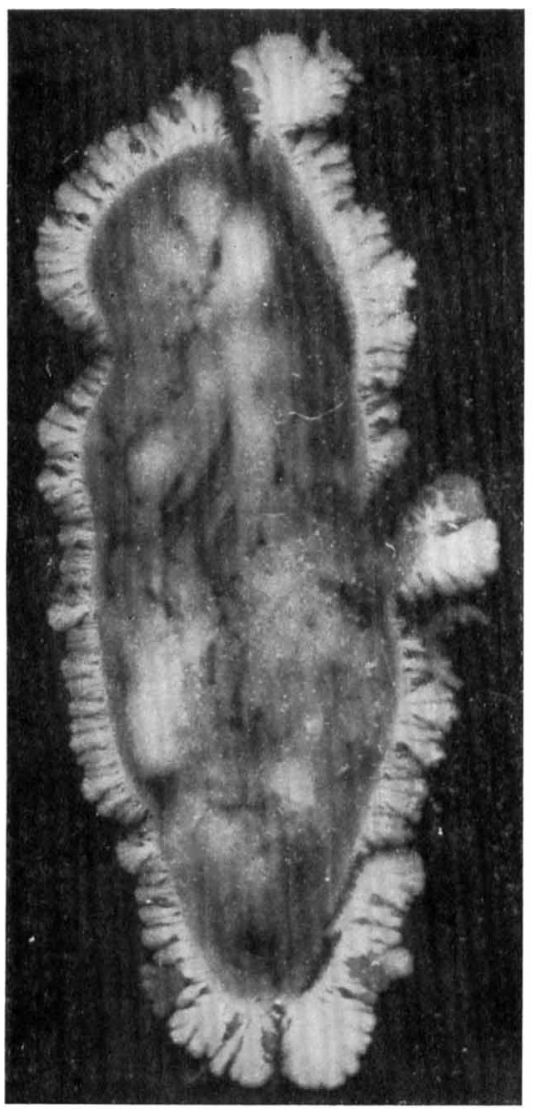

Fig. 9

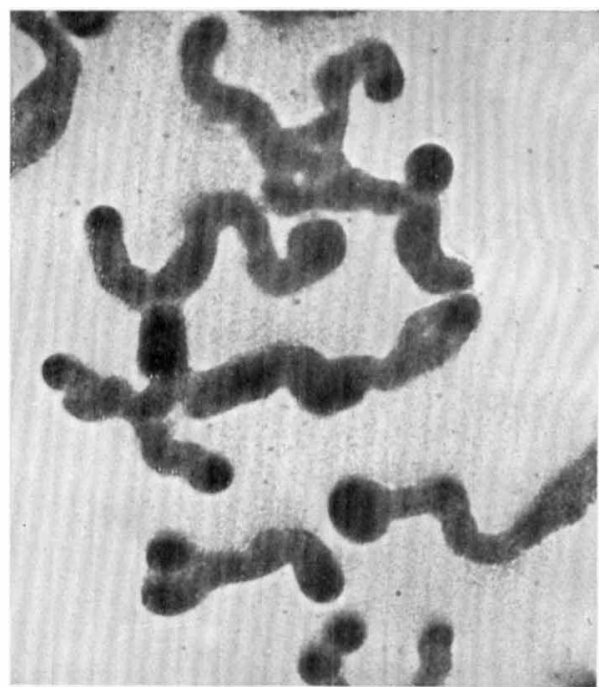

Fig. 8

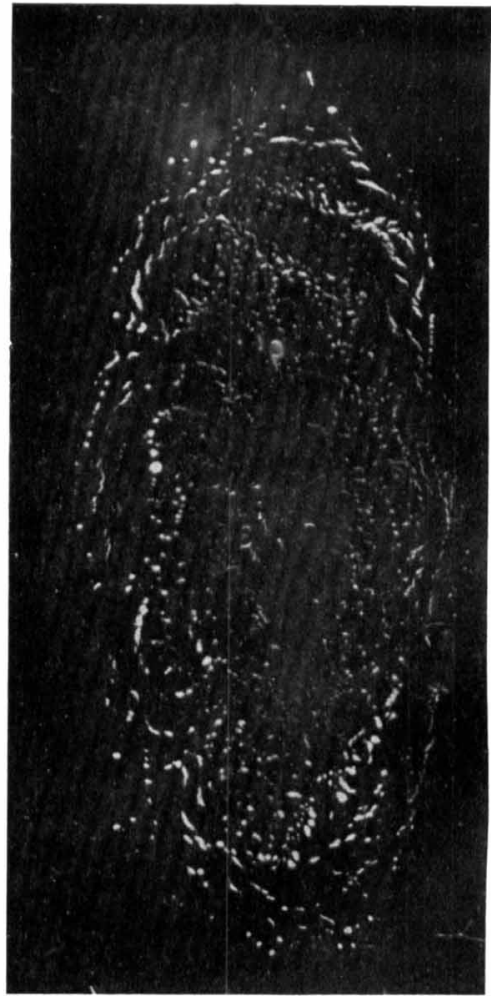

Fig. 10

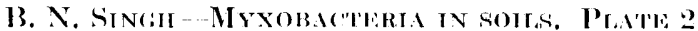

